\title{
In Vitro Interaction of Brazilian Strains of the Nematode- trapping Fungi Arthrobotrys spp. on Panagrellus sp. and Cooperia punctata
}

\author{
APS Gomes ${ }^{+}$, RS Vasconcellos*, ML Ramos*, MP Guimarães, AP Yatsuda**, \\ MCR Vieira-Bressan**
}

\begin{abstract}
Departamento de Parasitologia, Instituto de Ciências Biológicas, Universidade Federal de Minas Gerais, 31270-901 Belo Horizonte, MG, Brasil *Departamento de Veterinária, Universidade Federal de Viçosa, Viçosa, MG, Brasil **Departamento de Parasitologia, Instituto de Ciências Biomédicas, Universidade de São Paulo,

São Paulo, SP, Brasil
\end{abstract}

In vitro tests were carried out to verify the activity of 26 Brazilian isolates of predatory fungi of the genus Arthrobotrys on a free-living nematode (Panagrellus sp.) and on infective larvae of Cooperia punctata, a parasitic gastrointestinal nematode of cattle. The results showed that the free-living nematode Panagrellus sp. was the most preyed upon, compared to C. punctata, for all the fungal treatments. Also, variable predatory capacity was observed for different fungal isolates belonging to the same genus when applied to different nematode species.

Key words: nematode - trapping fungi - Arthrobotrys - nematodes - Cooperia punctata

Different hyphomycete predators have been tested against a range of animal-parasitic nematodes under laboratory conditions. The majority of studies investigating the biological control of this nematodes have involved the use of predatory fungi (Mendonza-de-Gives 1999). Nematode-destroying fungi produce traps along the hyphae. The development of these structures represents the fungus response to the presence of nematodes or to substances derived from them or to the presence of several other compounds of biological origin, being also induced by adverse culture conditions such as water and/or nutrient scarcity (Balan \& Gerber 1972). Hypha differentiation can occur within 24 $\mathrm{h}$ and various trapping structures can be produced (Pramer 1964). The isolates utilized in the tests were of the genus Arthrobotrys and these fungi produce each one tridimensional nets, consisting of one to three cells, covered by adhesive material (Barron 1977). After the nematode is captured, an infective bulb is produced from the internal wall of the trap and the nematode cuticle is broken and penetrated. Assimilative hyphae are produced along the nematode body and finally the content is absorbed by the fungus (Barron 1977). Diseases caused by animal parasitic nematodes are consid-

${ }^{+}$Corresponding author. Fax: +55-31-499.2829. E-mail: Alessandragomes@homenet.com.br

Received 22 August 2000

Accepted 8 March 2001 ered a major problem in animal husbandry in different regions and countries in the World (Charles \& Furlong 1996). The parasitic gastrointestinal nematode of cattle Cooperia are one of the most important and has a wide geographic distribution, however, it is most commonly found, and is of greatest economic importance, in tropical and subtropical areas. The free-living nematodes are one the most important groups of organisms in soil; they are higly abundant, with enormous diversity and are essencial for the functioning of different ecosystems. The Panagrellus sp. is used in various studies as a model, which is kept in various laboratories around the world, being used as a bait for isolation as well in predation tests on nematophagous fungi. Gomes et al. (1999) showed in trap tests on various nematodes that Panagrellus was more susceptible to predation by all the fungal isolates of genus Monacrosporium and Gomes et al. (2000) showed in trap tests on Panagrellus and Haemonchus place $i$ the same susceptibility to predation by isolates of genus Arthrobotrys. Gomes (1998) and Araujo et al. (1998) showed in vivo biological control of bovine parasites by A. robusta.

This work aimed to compare the activity of different isolates of the nematode-trapping fungus Arthrobotrys on the free-living nematode Panagrellus sp. and the cattle parasitic nematode C. punctata.

\section{MATERIALS AND METHODS}

Infective larvae (L3) of C. punctata were supplied by Department of Parasitology of the University of São Paulo (USP). 
Panagrellus (free-living nematodes) was originated from the Department of Phytopathology of the Federal University of Viçosa (UFV).

To obtain nematodes without faecal bacteria and fungi, they were processed according technique of Gomes et al. (2000).

The nematodes were counted using an optical microscope (10X), taking three $10 \mu \mathrm{l}$ aliquots, measuring the average and extrapolating the total volume.

Twenty six isolates of predatory fungi of the genus Arthrobotrys (Table) were kept in test tubes containing $2 \%$ potato-dextrose-agar (2\% PDA) at $4^{\circ} \mathrm{C}$ in a dark environment. These isolates comprised eight $A$. robusta isolates (A31, A35, A38, A39, A51, A134, A75a, A265); eight A. conoides isolates (A32, A40, A58, A74, A78, A151, A241, A266); four isolates of A. oligospora (A72, A110b, A125b, A183); two isolates of A. oviformis (A39d, A121b); two isolates of A. superba (A32c, A46) and one isolate of A. musiformis (A 144), originated from soils in several Brazilians localities (Table). Culture discs were removed from Petri dishes of $8.5 \mathrm{~cm}$ in diameter, containing $20 \mathrm{ml}$ of $2 \%$ PDA culture medium. The fungi grew on these dishes for seven days at $27^{\circ} \mathrm{C}$ in the dark; $7 \mathrm{~mm}$ diameter mycelium discs were removed from the PDA fungal culture edges, and transferred to Petri dishes containing $2 \%$ water-agar medium ( $2 \%$ WA) and $1 \%$ gentamycin (one drop/100 ml medium). These dishes were kept in an incubator at $27^{\circ} \mathrm{C}$ for five days in the dark. On the 6th day, 1 $\mathrm{ml}$ suspension containing 500 nematodes of each group or species was individually added to these dishes. Three replications were performed for each treatment. The dishes were kept in the dark at $27^{\circ} \mathrm{C}$. Every two days the dishes were checked (40x) and the captured nematodes counted.

The results were analyzed by descriptive analysis of panels.

\section{RESULTS}

Figure shows the results of the trap tests of fungal isolates on the two genus of nematodes. Isolate A183 was the most effective fungus against the two nematode groups. The isolates A144, A40, A32c, A32, A110b, A241 and A183 were the most effective against the genus $C$. punctata when compared to the other fungal treatments. The free-living nematodes (Panagrellus sp.) were more affected than the cattle parasitic nematode $(C$. punctata) after treatment with all the fungal iso-

\section{TABLE}

Arthrobotrys isolates, its culture and local of origin

\begin{tabular}{|c|c|c|c|}
\hline Isolates & & City and state in Brazil (year) & Crop \\
\hline A 74 & A. conoides & Dourados/MS (1991) & Corn \\
\hline A $125 b$ & A. oligospora & Rondonópolis/MT (1991) & Seringa $^{a}$ \\
\hline A $51 b$ & A. robusta & Matipó/SP (1991) & Soybean \\
\hline A 241 & A. conoides & Papanduva/SC (1993) & Garlic \\
\hline A $39 a$ & A. robusta & Viçosa/MG (1990) & Onion \\
\hline A 134 & A. robusta & Ipeúma/SP (1992) & Corn \\
\hline A279 & A. superba & Iraí de Minas/MG (1993) & Soybean \\
\hline A 72 & A. oligospora & Dourados/MS (1991) & Soybean \\
\hline A 35 & A. robusta & Atalaia/PR (1990) & Unknown \\
\hline A 40 & A. conoides & Jaguapitã/SP (1990) & Unknown \\
\hline A 32 & A. conoides & Jaguapitã/SP (1990) & Unknown \\
\hline A 31 & A. robusta & Jaguapitã/SP (1990) & Unknown \\
\hline A 144 & A. musiformes & Manaus/AM (1992) & Banana \\
\hline A 266 & A. conoides & Curitibanos/SC (1993) & Garlic \\
\hline A 265 & A. robusta & Flores da Cunha/RS (1993) & Garlic \\
\hline A 183 & A. oligospora & Cajuri/MG (1992) & Citrus \\
\hline A $39 d$ & A. oviformis & Viçosa/MG (1991) & Onion \\
\hline A 46 & A. superba & S. Vicente Ferrer/PE (1991) & Banana \\
\hline A 38 & A. robusta & Viçosa/MG (1990) & Corn \\
\hline A 58 & A. conoides & Viçosa/MG (1991) & Okra \\
\hline A 32c & A. superba & Viçosa/MG (1990) & Palm Tree \\
\hline A $110 b$ & A. oligospora & Lambari/MG (1991) & Beijo $^{b}$ \\
\hline A 75a & A. robusta & Dourados/MS (1991) & Coffee \\
\hline A 151 & A. conoides & Uberlândia/MG (1992) & Corn \\
\hline A $121 b$ & A. oviformis & Arinos/MG (1991) & Forest \\
\hline A 78 & A. conoides & Visc. do Rio Branco/MG (1990) & Rice \\
\hline
\end{tabular}

$a$ : a Brazilian rubber tree, $b$ : tropical flower 
lates. There was no difference in predation of freeliving nematodes by various fungal isolates but the isolates A46 and A144 were less effective to Panagrellus sp.

The isolates A32c and A183 were more effective against $C$. punctata, and the isolates A144 and A58 especially during the first days, while isolates A39d, A72 were quite effective for C. punctata during the last reading days.
The isolates of $A$. robusta could not be considered a good species as agent of biological control of C. punctata. Only three species (A39a, A51b, A265) showed significant results on $C$. punctata when they are compared with other strains, however this isolates of $A$. robusta were highly effective against free-living nematodes (except A51b).

No relationship was verified between the local of origin of the several isolates and effectiveness

\section{Cooperia punctata}

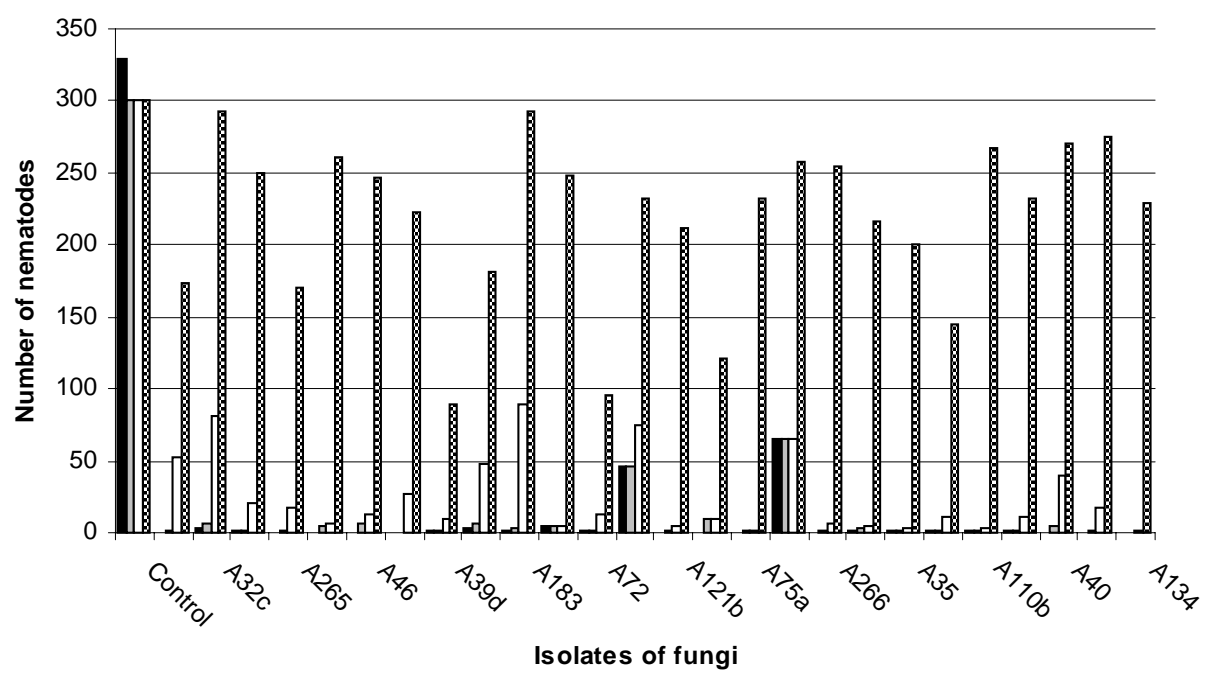

口Day $1 \quad \square$ Day $2 \quad$ aDay 3 : Day 4

Panagrellus sp.

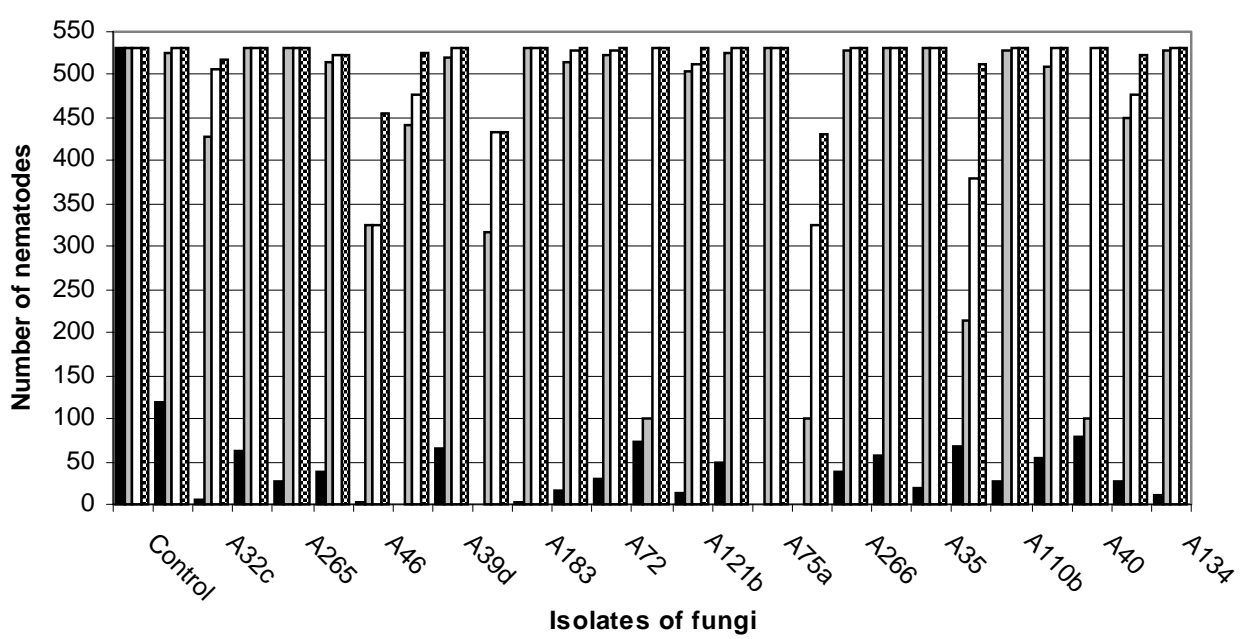

Day 1 aDay $2 \quad$ aDay 3 Day 4

Susceptibility of nematodes to predation by fungi. Data are reported as number of nematodes trapped on days 1 to 4 after 500 nematodes were exposed to Arthrobotrys robusta (isolates A31, A35, A38, A39a, A51b, A134, A75a, A265), A. conoides (isolates A32, A40, A58, A74, A78, A151, A241, A266), A. oligospora (isolates A72, A110b, A125b, A183), A. superba (A32c, A279, A46), A. oviformis (A39d, A121b) and A. musiformis (A144). Data are the means of measurements in triplicate. Note that a controls are variable. 
on predation. Ramos (2000) observed high genetic diversity of many isolates of genera Arthrobotrys by RAPD and that the isolates A183 and A51b could be differentiated from their respective species.

\section{DISCUSSION}

Nematodes are one of the most important groups of organisms in soil and they are essential for the functioning of different ecosystems. Freeliving nematodes play a very important role in soil by feeding on bacteria and fungi, thereby contributing to the decomposition and re-cycling of organic mater (Etema 1998). The possible use of biological control agents in the ruminant parasitic nematodes has been investigated and these antagonists offer environmentally sustainable method of control.

The results showed that the free-living nematode Panagrellus sp. was more preyed when compared to the nematode $C$. punctata with all fungal treatments and these tests are of great importance to the further use of these fungi in the biological control of nematodes, since free-living nematodes and cattle parasitic nematodes are generally associated in the environment.

Large numbers of isolates can be obtained through various baiting techniques, grown up and tested initially in vitro and then in vivo to observe if they have potential to control the parasites (Mendonza-de-Gives 1999). Another important aspect of in vitro tests is the selection of isolates which are effective against bovine nematodes parasites and not against the free-living nematodes, as the isolate A144 (A. musiformis).

In vitro tests continue to be possible in studies with nematophagous fungi, but they have limitations. They usually overestimate the activity of an agent by not allowing the nematode to escape or by not reproducing the rather common interferences found in soil and changes in the environment. Nevertheless, they have advantages such as a small physical space and shorter evaluation time. Moreover, there is a higher control that the fungus-nematode interaction is indeed taking place.

Facultative parasites such as nematode-trapping fungi have also limiting factors that militate against their use as biological control agents, one of the most important is the germination of spores and production of trapping structures in an environmental niche where they cohabit with the nematode population to be controlled and also with a num- ber of individuals from the fungivore soil fauna (Jaffe et al. 1997).

The Arthrobotrys isolates studied can be used as agents in the biological control of nematodes, becoming an a useful tool to solve the problems regarding helminthosis, but further studies are necessary for the selection of isolates with little damage or no to soil microfauna.

\section{REFERENCES}

Araújo JV, Gomes APS, Guimarães MP 1998. Biological control of bovine gastrointestinal parasites in southeastern by the nematode-trapping fungus Arthrobotrys robusta. Rev Bras Parasitol Vet 2: 117122.

Balan J, Gerber N 1972. Attraction and killing of the nematode Panagrellus redivivus by the predacious fungus Arthrobotrys dactiloides. Nematology 18: 163-173.

Barron GL 1977. The Nematode-destroying Fungi, Canadian Biological Publications, Guelph, 140 pp.

Charles PT, Furlong J 1996. A survey of dairy cattle worm control practices in southeast Brazil. Vet Parasitol 65: 65-73.

Ettema HC 1998. Soil nematode diversity species coexistence and ecosystem function. J Nematol 30: 159169.

Gomes APS 1998. Controle Biológico in Vivo de Nematódeos Parasitos Gastrintestinais de Bovinos pelo Fungo Arthrobotrys robusta e Atividade in Vitro de Isolados do Fungo Monacrosporium sobre Nematódeos, MSc Thesis, Universidade Federal de Viçosa, Viçosa, 82 pp.

Gomes APS, Araújo JV, Ribeiro RCF 1999. Differential in vitro pathogenicity of predatory fungi of the genus Monacrosporium for phytonematodes, freeliving nematodes and parasitic nematodes of cattle. Braz J Med Biol Res 32: 79-83.

Gomes APS, Ramos ML, Vasconcellos RS, Jensen JR, Vieira-Bressan MCR, Araujo JV 2000. In vitro activity of Brazilian strains of the predatory fungi Arthrobotrys spp. on free-living nematodes and infective larvae of Haemonchus placei. Mem Inst Oswaldo Cruz 95: 873-876.

Jaffe BA, Santos, PF, Muldoon AE 1997. Supression of nematophagous fungi by enchytraeid worms: a field exclosure experiment. Oecology 112: 412-423.

Mendoza-de-Gives P 1999. Interaction between Nematodes and Biocontrol Agents with Potential for Use in Biomanagement Systems, $\mathrm{PhD}$ Thesis, University of Nottingham, England, 219 pp.

Pramer D 1964. Nematode-trapping fungi. Science 144: 382-388.

Ramos ML 2000. Diversidade Genética de Isolados Arthrobotrys spp. por Marcadores RAPD e PCRRFLP do rDNA, MSc Thesis, Universidade Federal de Viçosa, Viçosa, 57 pp. 